\title{
Article
}

http://dx.doi.org/10.11646/phytotaxa.173.2.4

\section{Novelties in Myrtaceae: contributions to the Flora of the State of Sergipe, Brazil}

\author{
CAROLYN E. B. PROENÇA ${ }^{1,5}$, MARLA I. U. DE OLIVEIRA², MARCOS SOBRAL ${ }^{3} \&$ MYRNA F. LANDIM $^{4}$ \\ ${ }^{1}$ Departamento de Botânica, Universidade de Brasília - UnB, ICB Bloco D, Campus Darcy Ribeiro, Gleba A, CEP 70919-900, Brasília, \\ Distrito Federal, Brazil. \\ ${ }^{2}$ Departamento de Ciências Biológicas e da Saúde, Universidade Tiradentes - UNIT, Av. Murilo Dantas, 300, Bloco E, CEP 49032-490, \\ Aracaju, Sergipe, Brazil. \\ ${ }^{3}$ Departamento de Ciências Naturais, Universidade Federal de São João del-Rei, Praça Dom Helvécio, 74, Bairro Dom Bosco, CEP \\ 36301-160, São João del-Rei, Minas Gerais, Brazil. \\ ${ }^{4}$ Departamento de Biologia, Universidade Federal de Sergipe, Cidade Universitária Prof. José Aloísio de Campos, Bairro Rosa Elze, \\ São Cristóvão, CEP 49100-000, Sergipe, Brazil. \\ ${ }^{5}$ Author for correspondence: cproenca@unb.br
}

\begin{abstract}
This paper describes four new species and proposes a new synonym of Myrtaceae of particular relevance for the flora of Sergipe and Bahia, Brazil, either within Eugenia L. or Myrcia DC. The occurrence of Myrcianthes pseudomato (D.Legrand) McVaugh, the first species of the genus to be registered in Sergipe and the second species of the genus for Northeastern Brazil is noted, and a short description of the fruits of Eugenia brejoensis Mazine, described in 2008 based on flowering material only is also provided.
\end{abstract}

\section{Resumo}

Este artigo descreve quatro espécies novas e propõe um novo sinônimo de Myrtaceae de particular relevância para a Flora de Sergipe e da Bahia, Brasil, dentro de Eugenia L. ou Myrcia DC. A ocorrência de Myrcianthes pseudomato (D.Legrand) McVaugh, a primeira espécie do gênero a ser registrada em Sergipe e a segunda espécie do gênero para Nordeste do Brasil, é observada; e uma descrição dos frutos de Eugenia brejoensis Mazine, descrita em 2008 com base somente em material com flores, também é fornecida.

\section{Introduction}

The Myrtaceae are currently estimated to have 142 genera and c. 5500 species worldwide (Wilson 2011). Brazil is one of the major centers of diversity for this family with 24 genera and 986 species (Sobral et al. 2013). The family is exceptionally species-rich in the Atlantic coastal forests (Mata Atlâtica) and in the savannas (Cerrados) of southeastern Brazil, where they can make up $10 \%-15 \%$ of the species of the Angiosperm flora (Mori et al.1983, OliveiraFilho \& Fontes 2000). In the states in which the Atlantic coastal forests occur narrow endemism is common (MurraySmith et al. 2008, Sobral et al. 2013). Three state floras of Myrtaceae exist in Brazil, for Santa Catarina (Legrand 1972, 1977, 1978), Rio Grande do Sul (Sobral 2003) and now Sergipe (Proença et al. 2013), although there are on-going floras for other Brazilian states, such as the Distrito Federal, Goiás, Rio Grande do Norte, Tocantins and São Paulo.

Sergipe is the smallest Brazilian state with an area of c. $22,000 \mathrm{~km}^{2}$ ranging from $9^{\circ} 31^{\prime} 54^{\prime \prime}$ to $11^{\circ} 34^{\prime} 12^{\prime \prime}$ north to south and from $36^{\circ} 24^{\prime} 27^{\prime \prime}$ to $38^{\circ} 11^{\prime} 20^{\prime \prime}$ east to west (Franco 1983); it is also a coastal state, and the vegetation in the east is composed of a thin strip of Myrtaceae-rich complex of Atlantic forest and coastal white sand forest or scrub (Restinga) while the rest of the state is made up mostly of xerophytic vegetation (Caatinga) with a few islands of midelevation forest (Franco 1983). Based on the Myrtaceae, it appears that botanical exploration of Sergipe was later than most other Brazilian states and started in the 1970's. 
inflorescence is a wide, delicate panicle with up to 50 flowers; the fruits are not known, but the buds have a marked hypanthial cup and glabrous hypanthia, so the fruits can be presumed to be glabrous as well. M. spathulifolia has a shallow, dish-shaped hypanthial cup, narrow, raceme-like panicles and densely albo-velutinous young fruits.

\section{Myrcianthes Berg (1856: 315).}

Myrcianthes is a predominantly Andean genus of ca. 35 species distributed from Mexico to Chile (Grifo 1992, Landrum \& Kawasaki 1997, Govaerts et al. 2008). Nine species occur in Brasil and only one is currently known from the Brazilian Northeast, i.e., Myrcianthes fragrans Swartz (1788: 79) in Pernambuco (Sobral et al. 2013).

\subsection{Myrcianthes pseudomato (Legrand 1944: 477) McVaugh (1963: 493)}

This is a new occurrence for Brazil. The single collection of this species, made in Sergipe, closely matches the description by Grifo (1992) except for the number of ovules that is slightly higher (we found ca. 30 and she cites 1520). The stiff, cartilagineous leaf tip and pendulous placentation from a stalk arising near the middle of the locule is typical of the genus (Grifo 1992). A complete description is available in the Flora of Sergipe (Proença et al. 2013).

Examined material:-BRAZIL. Sergipe: Riachão do Dantas, June 2013, fl., Farias et al. 307 (ASE!, UB!).

Comments:- The citation of M. pseudomato for Paraná (Grifo 1992) is based on an erroneous identification detected by one of us (MS) and this species was, until now, presumed to not occur in Brazil (Sobral et al. 2013). The discovery of Myrcianthes pseudomato in Sergipe is surprising as its known distribution is Argentina and Bolivia (Govaerts et al. 2008). According to Eládio dos Santos (personal communication 2013), ASE herbarium technician, with wide experience of collecting in Sergipe, this species ocurrs almost always as a large tree. Fruiting specimens would be desirable, since they would provide additional evidence that this species is indeed Myrcianthes pseudomato.

\section{Acknowledgements}

We are grateful to ASE and RB Herbarium Curators for sending material on loan. CEBP and MS thank Ana Paula Prata and the Flora de Sergipe Project for the opportunity of visiting the ASE herbarium. CEBP also thanks The Sociedade Botânica do Brasil - Regional Nordeste for an invitation to give a talk on Myrtaceae in Sergipe during the XXXIII Reunião Nordestina de Botânica in 2010. MIUO thanks CAPES (Coordenação de Aperfeiçoamento de Pessoal de Nível Superior) and CNPq (Conselho Nacional de Desenvolvimento Científico e Tecnológico, grant 142180/2009-2) for her doctorate scholarship. Marta C.V. Farias (ASE) kindly recovered the identity of E.M. Carneiro and Marcelo L. Ianhez invested an immense amount of effort on very short notice to produce the illustration. Les Landrum, Renato Goldenberg and an anonymous reviewer made comments that improved the manuscript.

\section{References}

Aublet, J. (1775) Histoire des plantes de la Guiane françoise. Vol. 2. Pierre-François Didot, Paris, pp. 622-976, 1-160.

Berg, O. (1855-1856) Revisio Myrtacerum Americae. Linnaea 27: 1-472.

Berg, O. (1857) Myrtaceae. In: Martius, C.F.P. von. Flora Brasiliensis 14(1): 1-528.

Berg, O. (1859) Supplementum Myrtacearum. In: Martius, C.F.P. von. Flora Brasiliensis 14(1): 529-665.

Candolle, A.P. de, Audouin, J.V., Bourdon, I., Brongniart, A., Bory de Saint-Vincent, J.B.G.M. (1827) Dictionnaire classique d'histoire naturelle. Vol. 11. Rey et Gravier, Libraries-Editeurs/Baudouin Frèrer, Libraries-Editeurs, Imprimeurs de la société D'Histoire Naturelle, Paris. 616p.

Candolle, A.P. de (1828) Prodromus Systematis Naturalis Regni Vegetabilis. Vol. 3. Treuttel \& Würtz, Paris. 494p. http://dx.doi.org/10.5962/bhl.title.33901

CRIA (Centro de Referência em Informação Ambiental) (2013) speciesLink - busca simples. Available at: http://www.splink.org.br/índex (accessed 05 July 2013).

Cunha, M.C.L., Silva Júnior, M.C. \& Lima, R.B. (2013) A flora lenhosa na Floresta Estacional Semidecídua Montana do Pico do Jabre, PB. Agrária 8: 130-136.

Govaerts, R., Sobral, M., Ashton, P., Barrie, F., Holst, B.K., Landrum, L.R., Matsumoto, K., Mazine, F.F., Nic Lughadha, E., Proença, 
C.E.B., Silva, L.H.S., Wilson, P.G. \& Lucas, E.J. (2008) World Checklist of Myrtaceae. Vol. 1. Royal Botanic Garden, Kew. 455p. Grifo, F.T. (1992) A revision of Myrcianthes Berg (Myrtaceae). D. Phil. thesis, Cornell University.

Kobayashi, S. \& Langguth, A. (1999) A new species of titi monkey, Callicebus Thomas, from north-eastern Brazil (Primates, Cebidae). Revista Brasileira de Zoologia 16: 531-551.

http://dx.doi.org/10.1590/s0101-81751999000200018

Landrum, L.R. \& Kawasaki, M.L. (1997) The genera of Myrtaceae in Brazil: an illustrated synoptic treatment and identification keys. Brittonia 49(4): 508-536.

http://dx.doi.org/10.2307/2807742

Legrand, C.D. \& Klein, R.M. (1972) Mirtáceas. In: Reitz, P.R. (ed.) Flora Ilustrada Catarinense. Herbário Barbosa Rodriques, Itajaí, pp. 553-569.

Legrand, C.D. \& Klein, R.M. (1977) Mirtáceas In: Reitz, P.R. (ed.) Flora Ilustrada Catarinense. Herbário Barbosa Rodriques, Itajaí, pp. $570-730$.

Legrand, C.D. \& Klein, R.M. (1978) Mirtáceas In: Reitz, P.R. (ed.) Flora Ilustrada Catarinense. Herbário Barbosa Rodriques, Itajaí, pp.731-876.

Legrand, C.D. (1944) Tres arboles argentinas de la família de las Mirtaceas. Lilloa 10: 471-482.

Linné, C. von (1753) Species Plantarum. Vol. 2. Impensis Laurentii Salvii, Stockholm. Pp. 1200.

Mattos, J.R. (2008) Notas sobre Myrcia (Myrtaceae) do Brasil. Loefgrenia 126:1-6.

Mazine, F.F. \& Souza, V.C. (2008) A new species of Eugenia (Myrtaceae) from north-eastern Brazil. Botanical Journal of the Linnean Society 158: 775-777. http://dx.doi.org/10.1111/j.1095-8339.2008.00921.x

McVaugh, R. (1963) Tropical American Myrtaceae II. Notes on generic concepts and description of previously unrecognized species. Fieldiana, Botany 29: 393-532.

http://dx.doi.org/10.5962/bhl.title.2444

Mori, S., Boom, B., Carvalho, A.M. de \& Santos, T. dos (1983) Ecological Importance of Myrtaceae in an Eastern Brazilian Wet Forest. Biotropica 15: 68-70. http://dx.doi.org/10.2307/2388002

Oliveira-Filho, A.T. \& Fontes, M.A.L. (2000) Patterns of floristic differentiation among Atlantic forests in southeastern Brazil, and the influence of climate. Biotropica 32: 793-810. http://dx.doi.org/10.1111/j.1744-7429.2000.tb00619.x

Proença, C.E.B., Oliveira, M.I.U., Landim, M.F. (2013) Myrtaceae. In: Prata, A.P.N., Amaral, M.C.E., Farias, M.C.V., Alves, M.C. (orgs.) Flora de Sergipe, vol. 1. Gráfica e Editora Triumfo Ltda., Aracaju, pp. 364-430.

Silveira, N. J.E. (1985) Notas sobre o gênero Myrcia DC. (Myrtaceae) II. Roessleria 7: 65-68.

Sobral, M. (2003) A família Myrtaceae no Rio Grande do Sul, ed. 1. Editora Unisinos, São Leopoldo. 215p.

Sobral, M., Proença, C., Souza, M., Mazine, F. \& Lucas, E. (2013) Myrtaceae in Lista de Espécies da Flora do Brasil. Available from: http://floradobrasil.jbrj.gov.br/2013 (accessed 05 July 2013).

Souza-Alves, J.P., Fontes, I.P., Chagas, R.R.D. \& Ferrari, S.F. (2011) Seasonal Versatility in the Feeding Ecology of a Group of Titis (Callicebus coimbrai) in the Northern Brazilian Atlantic Forest. American Journal of Primatology 73: 1199-1209. http://dx.doi.org/10.1002/ajp.20990

Swartz, O. 1788. Nova genera \& species plantarum, seu, Prodromus descriptionum vegetabilium :maximam partem incognitorum quæ sub itinere in Indiam Occidentalem annis 1783-87. Acad. M. Swederi, Stockholm, Upsala \& Abo. Pp. 158. http://dx.doi.org/10.5962/bhl.title.433

Thiers, B. (2013) Index Herbariorum: a global directory of public herbaria and associated staff. Available from: http://sweetgum.nybg. org/ih/ (accessed 20 May 2013).

Wilson, P.G. (2011) Myrtaceae. In: Kubitzki, K. (ed.) The families and genera of vascular plants- Sapindales, Cucurbitales, Myrtaceae, vol. 10. Springer, Berlin, pp. 212-271. 